УДК 338.47. 338.1.

https://doi.org/10.33296/2707-0654-8(16)-06

ХРАПАЧ ВЛАДИСЛАВ

магістрант, Національний авіаційний

університет, м. Київ, Україна

ORCID ID: 0000-0002-0073-0914

\author{
АРЕФ'СВА ОЛЕНА \\ доктор економічних наук, професор, завідувач \\ кафедри економіки повітряного транспорту, \\ Національний авіаційний університет, м. Київ, \\ Україна
}

ORCID ID: 0000-0001-5157-9970

\title{
ФОРМУВАННЯ КОНКУРЕНТНОЇ ПЕРЕВАГИ АВІАКОМПАНІЇ НА ПІДСТАВІ РЕАЛІЗАЦІЇ БОРТОВОГО ХАРЧУВАННЯ
}

Анотація. У роботі була надана характеристика сутності конкурентних переваг. В статті обгрунтовується необхідність реалізації конкурентних переваг на ринку пасажирських авіаперевезень. Пропонується формування конкурентних переваг на основі бортового харчування та обгрунтовується привабливість таких переваг. У роботі аналізується ринок бортового харчування. Досліджуються особливості надання послуги бортового харчування в Україні. В статті виявляються основні проблеми та недоліки ринку бортового харчування в Україні. На основі проведених досліджень пропонуються заходи щодо перетворення недоліків ринку бортового харчування в конкурентну перевагу авіакомпаній. Реалізація запропонованих заходів дасть змогу авіаперевізнику якісно покращити свій імідж, мати особливу рису, яка буде значно посилювати попит на послуги підприємства, що характерно виділить авіапідприємство серед конкурентів i дасть змогу пасажиру втомити голод та отримати бажаний, в постмодерністському суспільстві, комфорт. А вже комфорт пасажирів $є$ великою конкурентною перевагою авіаперевізника.

Метою даної статті є теоретичне обгрунтування та розробка практичних рекомендацій заходів щодо формування конкурентних переваг авіакомпаній на основі реалізації бортового харчування. Актуальність обраної теми обумовлена насиченою конкурентною боротьбою авіакомпаній на ринку України, необхідністю компаній виборювати найменші переваги в той час, коли, на провідне направлення формування конкурентної переваги в світі, бортове харчування, зовсім не звертається увага.

\footnotetext{
(c) Українська інженерно-педагогічна академія

(c) ГО «Школа адаптивного управління сочіально-педагогічними системами»

(C) Храпач B., Ареф''єва О.
} 
Наукову новизну отриманих результатів складає розроблення рекомендацій щодо використання бортового харчування як елемента конкурентної боротьби. Практична цінність полягає у можливості використання рекомендацій на всіх авіапідприємствах України.

Ключові слова: конкурентна перевага, конкурентна боротьба, бортове харчування, кейтерінг, пасажирські авіаперевезення.

Вступ. Підприємство, функціонуючи на привабливому ринку, стикається 3 проблемою наявності великої кількості сильних конкурентів, що змушує його активно вдаватися до методів конкурентної боротьби та находити особливості, які будуть виділяти це підприємство серед інших. Але, конкуренти будуть проводити ті самі заходи, що зумовлює складність або неможливість досягнення класичних конкурентних переваг, наприклад, ресурсних. В такій ситуації постає проблема пошуку конкурентних переваг в нетипових направленнях, в додаткових видах діяльності підприємства. У роботі була надана характеристика сутності конкурентних переваг. Проаналізовано ринок бортового харчування. Досліджено особливості надання послуги бортового харчування в Україні. В роботі виявлені основні проблеми та недоліки ринку бортового харчування в Україні. На основі проведених досліджень було запропоновано заходи щодо перетворення недоліків ринку бортового харчування в конкурентну перевагу авіакомпаній.

Аналіз останніх досліджень та публікацій. Питанню формування конкурентних переваг авіапідприємств, забезпеченню ӥх конкурентоспроможності присвячено багато праць вітчизняних науковців. Здійснення дослідження роботи спирається на наукові праці таких авторів: Ареф’єва О.В. [1, 2], , Сімкова Т. О. [1], Лисиця Ю. Б. [1], Кравчук Н.М. [2], Катан М.Я. [2], Троян А.В [8], Чорна О.В. [9] й інших, Закони України, офіційні заяви Міністерства Інфраструктури України [4].

\footnotetext{
(C) Українська інженерно-педагогічна академія

(c) ГО «Школа адаптивного управління сочіально-педагогічними системами»

(C) Храпач B., Ареф''єва О.
} 
Формування цілей статті. Метою даної статті $\epsilon$ теоретичне обгрунтування та розробка пропозицій формування конкурентних переваг за рахунок бортового харчування в умовах національного ринку.

Виклад основного матеріалу. Конкурентна перевага - це характерна риса, притаманна товару або підприємству, яка якісно виділяє його серед конкурентів надаючи підприємству або товару унікальну особливість. Ця особливість зумовлює доцільність реалізації товару або виду діяльності та дозволяє вести конкурентну боротьбу.

Формування конкурентної переваги потрібно починати з аналізу ринку, що перетікає в аналіз конкурентного середовища. На основі цього аналізу знаходяться вади ринку, ніким не реалізовані можливості. На основі цих можливостей розробляються рекомендації щодо створення конкурентних переваг.

Доцільно почати з відомостей про ринок пасажирських авіаперевезень. Як повідомляють зарубіжні інформаційні агентства, щорічно авіаційним транспортом перевозиться 1,6 млрд пасажирів. Частка авіаційного транспорту у світовому пасажирообігу близько 10\%. Ріст частки пасажирообороту спричиняється тим, що авіаційний транспорт дозволяє в умовах необхідності постійної мобільності у населення досить швидко та відносно дешево задовільнити цю потребу. Така необхідність у мобільності в першу чергу присутня в країнах 3 великою територією. Тому, в структурі пасажиро перевезень авіаційним транспортом майже 70\% є перевезення на внутрішніх авіалініях. Також велику роль грають перевезення в країни, до яких важко дістатися через відстань або географічні перепони. В Україні найбільшими авіакомпаніями є «Міжнародні авіалінії України», «СкайАп», «Азур Ейр Україна» та «Роза Вітрів». Більшість регіональних перевезень здійснюють «Міжнародні авіалінії України», «СкайАп», «Мотор Січ Ейрлайнс», «Роза Вітрів» та «Ян Ейр».

\footnotetext{
(C) Українська інженерно-педагогічна академія

(c) ГО «Школа адаптивного управління сочіально-педагогічними системами»

(C) Храпач B., Ареф''єва О.
} 
Як було зазначено вище, в Україні відбувається бурхливий ріст авіаперевезень. 3 кожним роком кількість пасажирів збільшується в межах 10\%. Це є гарним показником по галузі в світовій практиці. Нажаль, основний ріст відбувається за рахунок міжнародних перевезень, але серед пасажиропотоку на внутрішніх рейсах прослідковується мале, близько 5\%, але стабільне зростання. Внутрішні рейси по Україні обслуговують 14 авіакомпаній, а міжнародні - 18 авіакомпаній. Конкуренція серед міжнародного сполучення ділиться на загальну, разом з іноземними компаніями, та внутрішню, 3 українськими в деякій мірі монополістами. На цьому ринку конкуренція знаходиться на етапі млявої боротьби, що не скажеш про внутрішні авіасполучення. На ринку внутрішніх перевезень відбувається досить жвава боротьба. Розпочавши свою діяльність в листопаді 2018 року, авіакомпанія «Буковина» за перше півріччя 2019 року стала на 5 місці по кількості пасажирських перевезень в країні взагалі. Ми нагадаємо, що ці 5 компаній, включаючи «Буковина», склали 97\% всіх пасажирських перевезень за цей період [4]. Це говорить, що компанія, яка серйозно орієнтується на внутрішній ринок, змогла з спочатку своєї діяльності скласти конкуренцію найбільшим внутрішнім авіаперевізникам. Це $є$ ще одним підтвердженням бурхливості конкуренції на внутрішніх перевезеннях. Зважаючи на ситуацію, що склалося, авіакомпаніям на міжнародних перевезеннях буде необхідно отримати конкурентні переваги для пожвавлення конкурентної боротьби за пасажирів. Що стосовно авіакомпаній на внутрішніх авіалініях, то для них, навіть незначна зміна в репутації, у власному обслуговуванні пасажирів, дасть значну конкурентну перевагу. Проаналізувавши відомості про ринок пасажирських перевезень та обгрунтувавши необхідність в здобуті конкурентних переваг авіакомпаніями на внутрішньому та зовнішньому ринку, перейдемо до аналізу національного ринку бортового харчування. 
В Україні, заради виживання авіаційної галузі, вона була частково віддана під приватизацію. Приватизація деяких служб дала змогу зменшити об'єм фінансових зобов'язань державних підприємств галузі. Таким чином, більшість літного составу перейшли до новостворених авіакомпаній, в тому числі до державних, а частина служб з обслуговування літаків та пасажирів перейшла до хендлінгових компаній. В тому числі до них перейшли функції з поставок бортового харчування. Ці компанії об’єднали в собі декілька функцій, але основними для них залишилися поставка палива для літаків та прийом пасажирів. Тому, не досить розвинуту в нашій країні послугу із забезпечення бортового харчування було передано до кейтерингових компаній, які займаються постачанням харчування взагалі. Основними постачальниками борт харчування в Україні є «Скай Фуд Сервісес» [6], який забезпечує міжнародні рейси компанії «Міжнародні авіалінії України» [5] та «Роза Вітрів» [7]; «АвіаСервіс», який $є$ постачальником для декількох міжнародних рейсів невеликих компаній; та інші кейтерингові компанії, які заключають сезонні контракти. В цілому, ринок борт харчування має монополістичний характер через відсутність суттєвого попиту у авіакомпаній. Ситуація складна на всіх видах рейсів та у всіх компаній. Виключенням $є$ лише іноземні авіакомпанії, де всі ці процеси і послуги наладжені, але вони в більшості не використовують послуги вітчизняних кейтерингових фірм. Для розбору ринку бортового харчування в першу чергу потрібно розділити його на забезпечення бортового харчування внутрішніх рейсів та міжнародних. Спрощена схема забезпечення попиту на бортове харчування зображена в таблиці 1.

\footnotetext{
(C) Українська інженерно-педагогічна академія

(c) ГО «Школа адаптивного управління соціально-педагогічними системами»

(C) Храпач B., Ареф''єва О.
} 
Таблиця 1

Спрощена схема забезпечення попиту на бортове харчування *

\begin{tabular}{|c|c|c|c|c|c|}
\hline \multicolumn{2}{|c|}{ «Скай Фуд Сервісес» } & \multicolumn{2}{|c|}{ «АвіаСервіс» } & $\begin{array}{c}\text { «Ройал } \\
\text { кейтерінг» }\end{array}$ & $\begin{array}{c}\text { Інші кейтерінгові } \\
\text { фірми }\end{array}$ \\
\hline $\begin{array}{c}\text { Внутрішні } \\
\text { рейси }\end{array}$ & $\begin{array}{c}\text { Міжнародні } \\
\text { рейси }\end{array}$ & \multicolumn{2}{|c|}{ Міжнародні рейси } & $\begin{array}{l}\text { Міжнародні } \\
\text { рейси }\end{array}$ & $\begin{array}{c}\text { Міжнародні } \\
\text { рейси }\end{array}$ \\
\hline \multirow[t]{2}{*}{$\langle\mathrm{MAУ} »$} & \multirow[t]{2}{*}{ «MAУ» } & $\begin{array}{c}\text { «Мтор } \\
\text { Січ } \\
\text { Ейрлайнс» }\end{array}$ & $\begin{array}{c}\text { Короткостро- } \\
\text { кові } \\
\text { контракти }\end{array}$ & $\begin{array}{l}\text { «Азур Ейр } \\
\text { Україна» }\end{array}$ & \multirow[t]{3}{*}{$\begin{array}{c}\text { Короткострокові } \\
\text { та разові } \\
\text { контракти }\end{array}$} \\
\hline & & «Ян Ейр» & $\begin{array}{c}\text { Короткостро- } \\
\text { кові } \\
\text { контракти } \\
\end{array}$ & «СкайАп» & \\
\hline $\begin{array}{c}\text { «Роза } \\
\text { Вітрів» }\end{array}$ & $\begin{array}{c}\text { «Роза } \\
\text { Вітрів» }\end{array}$ & $\begin{array}{c}\text { Інші } \\
\text { компанії }\end{array}$ & $\begin{array}{c}\text { Разові } \\
\text { контракти }\end{array}$ & $\begin{array}{c}\text { Інші } \\
\text { авіакомпанї з } \\
\text { короткостро- } \\
\text { ковими } \\
\text { контрактами }\end{array}$ & \\
\hline
\end{tabular}

*Розроблено авторами

Почнемо розбір ринку 3 міжнародних рейсів. В Україні здійснюють міжнародні рейси більше десятка вітчизняних фірм. Основними є «Міжнародні авіалінії України» [5], «Роза вітрів» [7], «Азур Ейр Україна». На їх прикладі ми розберемо цей сектор ринку. Як правило, міжнародні рейси $\epsilon$ середньомагістральними (від 2-3 годин польоту до 6 годин) та дальньомагістральними (від 6 годин до 12 годин, у випадку з надтривалими рейсами - більше 12 годин). Найрозвинутіше бортове харчування в компанії «МАУ». В неї представлений найширший асортимент та постійні сезонні зміни. Постійне меню налічує 9 постійних наборів та більше двох десятків змінних наборів та блюд. В компанії прийнято обов'язкове харчування після 4 годин польоту. Авіакомпанія пропонує 3 послуги з бортового харчування [5; 6]. Перша послуга має назву «BUY ON BOARD». B неї входять: легкі закуски, паніні, напої алкогольні та без алкоголю, чай та кава, які кожен пасажир може купити на борту літака, скориставшись карткою або наявними грошима. Ця послуга доступна в економ-класі на всіх рейсах компанії, крім внутрішніх рейсів по Україні. Друга послуга має назву «PRE-ORDER MEAL». Вона (c) Українська інженерно-педагогічна академія
(c) ГО «Школа адаптивного управління сочіально-педагогічними системами»
(c) Храпач В., Ареф'єва О. 
доступна на всіх регулярних та чартерних рейсах компанії, для пасажирів економного, економ-преміум та бізнес-класу. Виключення складають надтривалі рейси до Києва. В надтривалих рейсах з Києва до Бангкоку, Делі, Нью-Йорка, Торонто, Санья ця послуга $є$ додатковою до безкоштовного харчування. Додатково зауважимо, що у бізнес-класі безкоштовне харчування надається на всіх рейсах. Мета цієї послуги надання пасажирам змоги обрати власне меню, заплативши за нього за 24 години до рейсу, якщо рейс з Києва, та за 36 годин до рейсу, якщо рейс з іншого міста. Виключення складають рейси по Україні, в них меню скорочується до салатів та паніні на вибір. Третя послуга - це «Безкоштовне спеціальне харчування». Воно полягає у тому, що при покупці білету, в якому присутнє безкоштовне харчування, а саме бізнесклас на всіх рейсах, економ-преміум на міжнародних рейсах та економ-клас на надтривалих рейсах, пасажири мають змогу обрати собі спеціальне меню, в яке входить: кошерні, вегетаріанські, халяльні, без вмісту свинини, морепродукти (тільки для бізнес класу) та харчування для дітей від 2 до 10 років. Головною умовою є обов’язкове уточнення бажаного набору при покупці білету.

Стосовно авіакомпанії «Роза Вітрів», то вони надають на всіх рейсах безкоштовно питну воду, а на міжнародних дають змогу обрати при покупці білета власне так зване «Небесне меню». Це меню реалізується тією кейтеринговою фірмою, що робить меню для «МАУ», але має значно менше страв. Особливістю $є$ те, що зміна меню здійснюється в залежності від часу польоту, а якщо страви замовляються завчасно, то можливо обрати будь-яке меню (в тому числі спеціальне) без обмежень, бо набори їжі, крім виключних страв, надаються в спеціальних контейнерах, які зручно взяти собою. Безкоштовне харчування цією компанією надається лише у бізнес класі.

Наступна компанія, це «Азур Ейр Україна». Ця компанія надає послуги бортового харчування лише на рейсах тривалістю від 6 годин. На рейсах до 6 годин пропонуються закуски, чай та кава з бортового бару, за додаткову плату.

\footnotetext{
(c) Українська інженерно-педагогічна академія

(c) ГО «Школа адаптивного управління сочіально-педагогічними системами»

(C) Храпач B., Ареф''єва О.
} 
На рейсах більше 6 годин компанія надає дворазове обов'язкове безкоштовне харчування та безалкогольні напої.

Стосовно бортового харчування на внутрішніх рейсах, більшість рейсів по Україні виконують не міжнародні гіганти (по міркам України) такі як «МАУ», а досить великий набір компаній. Ця ситуація схожа на авіаперевезення в Туреччині, де більшість авіакомпаній сконцентрована на внутрішньому ринку. Офіційно з 2011 року бортове харчування на внутрішніх рейсах та на рейсах тривалістю менше 2 годин не надається, також, в більшості компаній були ліквідовані послуги бару. Зауважимо, що в більшості фірм залишилося бортове харчування для бізнес-класу, але не для всіх пасажирів цього класу воно безкоштовне. Бортове харчування на внутрішніх рейсах було відмінено у 2011 році через те, що в цьому році збільшилася ціна на ряд базових послуг аеропортів в межах 17\%, також зросли ціни на аеронавігаційне обслуговування «Украерорухом» на $27 \%$ та зросла ціна на паливо. Все це збільшило фінансове навантаження на авіакомпанії, та вони вирішили відмовитись від харчування для скорочення росту цін на квитки. Така ситуація призвела до вимушеного росту цін на поставку бортового харчування в межах $25 \%$, що стало кінцевою крапкою у відмові від бортового харчування на внутрішніх рейсах взагалі, в тому числі від барів.

Отже, ринок бортового харчування у секторі міжнародних рейсів знаходиться на сталій позиції. Нічого нового не впроваджуються, а компанії лідери, в більшості, навіть не намагаються ввести навіть економне, урізане харчування на середньомагістральних рейсах та нижче. Звісно, в деяких компаніях виключення робиться для пасажирів бізнес-класу, але, як правило, вони не складають собою більшість пасажирів літака. Цікаво, що ринок бортового харчування, в країнах з провідними авіа мережами, має бурхливий ріст та пропонує покупцям все, що вони забажають, та боряться за доступність цих послуг, для підвищення попиту та створення конкурентної переваги.

\footnotetext{
(c) Українська інженерно-педагогічна академія

(c) ГО «Школа адаптивного управління сочіально-педагогічними системами»

(C) Храпач B., Ареф''єва О.
} 
Стосовно бортового харчування на внутрішніх авіалініях, то в Україні не має ніяких змін, незважаючи на те, що існують методи та підходи реалізації бортового харчування без суттєвого впливу на вартість польотів.

Отже, у зв’язку з таким становищем ми пропонуємо ряд заходів, які зможуть створити конкурентну перевагу для авіапідприємств та покращити їхнє становище за рахунок бортового харчування, яке є дуже недооціненим напрямком діяльності в Україні. Пропозиції будуть розділені на ті, що більш підходять для міжнародних авіаційних сполучень, та ті, що гарно прижилися би на внутрішніх авіалініях. В загальному вигляді, пропозиції представлені в таблиці 2.

Таблиця 2

Пропозиції створення конкурентних преваг на основі бортового харчування *

\begin{tabular}{|l|l|l|}
\hline \multicolumn{3}{|c|}{ Пропозиції } \\
\hline $\begin{array}{l}\text { Мведення особливої кухні на туристичних } \\
\text { напрямках }\end{array}$ & $\begin{array}{l}\text { залучення до відмови від багажу на внутрішніх } \\
\text { рейсах за рахунок бортового харчування, яке } \\
\text { включене у вартість квитка без багажу }\end{array}$ \\
\hline $\begin{array}{l}\text { введення безкоштовного сніданку для пасажирів, які летять в час } 37.00 \text { до 8.30, без } \\
\text { значних витрат з боку авіакомпанії }\end{array}$ \\
\hline $\begin{array}{l}\text { реалізація послуги їжі } 3 \text { бажаного } \\
\text { ресторану }\end{array}$ & впровадження пісної кухні на час постів \\
\hline $\begin{array}{l}\text { створення особливого вишуканого продукту, який може стати візитною карткою } \\
\text { підприємства }\end{array}$ \\
\hline
\end{tabular}

*Розроблено авторами

Першою пропозицією на міжнародних рейсах буде введення особливої кухні на туристичних напрямках. Мається на увазі, що авіакомпанія може запропонувати клієнтам скуштувати особливу страву, яка $\epsilon$ традиційна в державі або в місті прибуття. Такі дії можуть реалізовуватися разом 3 туристичними фірмами, так як ніхто цього не робив, це може викликати інтерес у споживачів, а в більшій мірі у туристичних фірм, які збільшать пасажиропотік. Для реалізації цієї пропозиції не потрібно встановлювати нові часові рамки для борт харчування та проводити застереження, як у разі, якщо б (C) Українська інженерно-педагогічна академія
(C) ГО «Школа адаптивного управління сочіально-педагогічними системами»
(C) Храпач В., Ареф'єва О. 
ця страва входила до безкоштовного харчування. Потрібно лише ввести їі в меню, яке надається авіакомпаніями на вибір, та в меню акцентувати увагу саме на цій страві.

Наступна пропозиція - це введення безкоштовного сніданку для пасажирів. Справа в тому, що більшість рейсів проходить до обіду та у вечері. Мінімальна кількість часу, якого потрібно для того щоб проснутися та дістатися аеропорту, це 2 години 3 урахуванням швидкого проходження реєстрації. Але навіть таке буває не часто. Якщо припустити, щоб на рейс о 7.30, людині потрібно встати о 5.30, бо їй потрібно поїсти, одягтись, доїхати до аеропорту та пройти реєстрацію, то людині аби виспатися, треба значно раніше лягти. Це не завжди зручно. Тому, аби збільшити час сну для людей, авіакомпанії можуть впровадити безкоштовні сніданки для всіх пасажирів, які летять в час 37.00 до 8.30. Таке піклування про клієнтів однозначно дасть покращення репутації компанії за рахунок позитивних емоцій. Цей проект можливо реалізувати без значних витрат. Справа у тому, що серед населення, особливо у молодого покоління, популярно їсти легкі сніданки з чашечкою кави. Кава є безкоштовною у більшості авіакомпаній на міжнародних рейсах. А легким сніданком можуть бути круасани. Їх вартість, залежно від виробника, становить до 0,7 євро. Особливість продукту в тому, що він не потребує особливих умов зберігання і його можливо брати на два рейси не піклуючись про те, що ті продукти, які не будуть з'їдені, зіпсуються.

Наступна пропозиція, це реалізація послуги їжі з бажаного ресторану. Ця послуга не є нова. Вона успішно реалізується в Америці та Британії. При завчасному замовлені, пасажир може обрати будь-яку страву з будь-якого ресторану міста з усіма побажаннями. Ця страва буде доставлена на літак i подана пасажиру. Розрахунки за їжу та їі транспортування проходять безпосередньо з рестораном, без участі авіакомпанії. Таким чином, задоволення

\footnotetext{
(C) Українська інженерно-педагогічна академія

(c) ГО «Школа адаптивного управління сочіально-педагогічними системами»

(C) Храпач B., Ареф''єва О.
} 
примх клієнтів, не маючи при цьому додаткових витрат, дає змогу вигідно покращити імідж авіакомпанії, тим збільшити іiі дохід.

Наступна пропозиція - це створення особливого вишуканого продукту. Покупець бажає вражень, тому авіапідприємство може впровадити особливий кондитерський або пекарський виріб, який міг би стати візитною карткою підприємства. Цей виріб обов'язково повинен мати ексклюзивну форму, зовнішній вигляд або упаковку, яка би асоціювалася у споживача саме 3 цією подорожжю, авіакомпанією. В залежності від виробу, якщо це особливе тістечко, його можливо давати пасажирам безкоштовно до кави. Такі вироби мають змогу відносно довго зберігатися, що дасть змогу реалізувати один запас ще й на наступному рейсі, або на рейсі назад. Ціна таких виробів не перевищує 1 євро, що буде мати незначне відображення навіть на ціні білету. У разі впровадження цієї ідеї, доцільно відмовитись від прибутку з продажу такого особливого продукту, що значно знизить вартість продукту, а отримати ефект за рахунок збільшення попиту на послуги авіакомпанії.

Авіакомпанії хочуть скоротити свої витрати часу та витрати на обслуговування багажу клієнтів. Причиною цього є те, що при короткотривалих рейсах не має у людей великої необхідності перевозити власні речі більше ручної поклажі, через це, об’єм робіт, затраченого часу та затрачених коштів на обслуговування багажу $\epsilon$ не пропорційний до результату. Авіакомпанії намагаються спонукати людей до відмови від громіздкого багажу. Одним із способів залучення до відмови, може стати бортове харчування. Під ідеєю витягти з валізи їжу для ще необхідної речі, яку можна перекласти з багажу у ручну поклажу, компанії запропонують пасажирам їжу на борту. Цю їжу можна включити у вартість квитка без багажу. Головною умовою є те, щоб ціна харчування не перевищувала мінімальну вартість послуги 3 обслуговування багажу. Таким чином, залишиться економія для пасажирів та харчування. Оскільки, більшість внутрішніх рейсів мають тривалість польоту близько однієї 
години, а перші 20 хвилин зліт та ще 15 хвилин, це посадка, то штатний состав персоналу борту не встигне обслугувати всіх пасажирів (це ще викликано тим, що деякі внутрішні направлення в Україні обслуговують середньомагістральні літаки), їжа, яка буде запропонована, повинна не потребувати підігріву, мати зручну упаковку, а може навіть особливу упаковку, за допомогою якої можливо завчасно роздати їжу пасажирам. Також, їжа повинна відповідати умовам зберігання, мати чіткі стандартизовані параметри ваги, розмірів та мати не малий строк придатності. Все це, та враховуючи те, що мінімальна вартість стандартної послуги з обслуговування багажу складає 83 гривні, а це означає, що вартість їжі неповинна перевищувати 83 гривні, ми пропонуємо впровадити на внутрішніх рейсах по Україні в склад бортового харчування замість послуги з обслуговування багажу сендвічі (паніні), випічку (круасани, пироги з будьякою начинкою на вибір пасажира) та високоенергетичну їжу (шоколадні батончики, харчовий виріб «Равлик»). Впровадження такого бортового харчування призведе до зниження витрат 3 обслуговування багажів авіакомпанією, збереження економії для пасажирів, адже вартість запропонованих виробів не перевищує 1 євро (важливо, що вартість цих виробів не має суттєвих коливань), що при мінімальній ціні за багаж у 83 гривні призведе до економії пасажиром щонайменше 50-и гривень та дасть змогу пасажиру втомити голод і отримати комфорт.

Ще однією пропозицією є впровадження пісної кухні на час постів. Ця пропозиція може реалізовуватись на всіх рейсах. Підчас посту авіаперевізник може замінити 10\% всього бортового меню в літаках на овочеві страви без м’яса, молочних продуктів та яєць. Практика реалізації цього проекту буде мати підтримку серед громадян. Зважаючи на те, що конфесійну більшість в Україні складає Християнство, доцільно впровадити меню не лише для всіх інших релігійних вірувань, яке вже є в більшості авіаперевізників, але й для християн.

\footnotetext{
(c) Українська інженерно-педагогічна академія

(c) ГО «Школа адаптивного управління соціально-педагогічними системами»

(C) Храпач B., Ареф'євва О.
} 
Висновки. Отже, сутність конкурентної переваги полягає у наданні підприємству чи товару особливої риси, яка якісно виділить його серед конкурентів і підтримає конкурентну боротьбу.

Проаналізувавши відомості про ринок пасажирських авіаперевезень, ми дійшли до висновку, що на обох напрямах цього ринку, а саме на внутрішніх авіалініях та міжнародних, $є$ потреба в нових конкурентних перевагах. Дослідивши національний ринок бортового харчування, ми дійшли до висновку, що бортове харчування, як конкурентна перевага, зможе найкраще задовільнити цю потребу, адже ринок бортового харчування в Україні є зовсім недооцінений.

Зважаючи на отримані висновки досліджень, ми запропонували заходи, що дадуть змогу будь-якій авіакомпанії отримати конкурентну перевагу за допомогою бортового харчування. Ми запропонували реалізацію таких заходів: введення особливої кухні на туристичних напрямках; залучення до відмови від багажу на внутрішніх рейсах за рахунок бортового харчування, яке включене у вартість квитка без багажу; введення безкоштовного сніданку для пасажирів, які летять в ранній час; реалізація послуги їжі 3 бажаного ресторану; впровадження пісної кухні на час постів; створення особливого вишуканого продукту, який може стати візитною карткою підприємства.

Реалізувавши ці заходи, будь-яке авіапідприємство зможе отримати суттєву конкурентну перевагу за рахунок бортового харчування та тим самим розвинути або започаткувати розвиток національного ринку бортового харчування.

\section{Використана література}

1. Ареф'єва О.В., Сімкова Т.О., Лисиця Ю.Б. Організаційноекономічне забезпечення управління якістю послуг авіатранспортних підприємств. Бізнес Інформ. 2018. №12. С. 224-232.

\footnotetext{
(C) Українська інженерно-педагогічна академія

(c) ГО «Школа адаптивного управління сочіально-педагогічними системами»

(C) Храпач B., Ареф''єва О.
} 
2. Ареф'єва О.В., Кравчук Н.М., Катан М.Я. Теоретичні основи управління конкурентоспроможністю авіатранспортного підприємства. Проблеми економіки. 2018. № 4. С.127-134.

3. Архіпов В.А., Русавька В.В. Організація обслуговування у закладах ресторанного господарства. Київ. 2017. 408 с.

4. Офіційний сайт Міністерства Інфраструктури України [Електронний ресурс]. Режим доступу: https://mtu.gov.ua

5. Офіційний сайт ПрАТ «Міжнародні авіаліній України» [Електронний ресурс]. Режим доступу: https://www.flyuia.com.

6. Офіційний сайт TOB «SkyFoodsService» [Електронний ресурс]. Режим доступу: https://skyfoodservice.com.ua/.

7. Офіційний сайт ТОВ «Роза Вітрів» [Електронний ресурс]. Режим доступу: https://www.windrose.aero.

8. Троян А. В. Класифікація та можливості досягнення конкурентних переваг підприємством. Ефективна економіка. 2013. № 11. - Режим доступу: http://nbuv.gov.ua/UJRN/efek_2013_11_53.

9. Чорна О.В. Конкурентні переваги підприємства та методи і шляхи ïx визначення. - Режим доступу: http://oldconf.neasmo.org.ua/node/491.

\section{References}

1. Arefieva O.V., Kravchuk N.M., Katan M.Y. Theoretical bases of management of competitiveness of the air-transport enterprise. Problem of economy. 2018. № 4. p.127-134.

2. Arefieva O.V., Simkova T.O., Lysytsia Yu.B. Organizationally economic ensuring quality management of services of the air-transport enterprises. Business inform. 2018. №12. p. 224-232.

3. Arkhipov V.A., Rusavka V.V. The organization of service in institutions of restaurant economy. Kiev. 2017. 408 p.

4. Official site of the Ministry of infrastructure of Ukraine [Electronic resource]. Access mode: https://mtu.gov.ua.

5. Official site PC "International airlines of Ukraine" [Electronic resource]. Access mode: https://www.flyuia.com.

6. Official site LLP "SkyFoodsService" [Electronic resource]. Access mode: https://skyfoodservice.com.ua/.

7. Official site LLP "Wind rose" [Electronic resource]. Access mode: https://www.windrose.aero.

8. Troian A.V. Classification and possibilities of achievement of competitive advantages by the enterprise. Access mode: http://nbuv.gov.ua/UJRN/efek $2013 \quad 1153$.

9. Chorna O.V. Competitive advantages of the enterprise and methods and ways of their definition. Access mode: http://oldconf.neasmo.org.ua/node/491.

\footnotetext{
(C) Українська інженерно-педагогічна академія

(c) ГО «Школа адаптивного управління соціально-педагогічними системами»

(C) Храпач В., Ареф'єва О.
} 


\title{
ХРАПАЧ ВЛАДИСЛАВ
}

магистрант, Национальный авиационный университет, г. Киев, Украина

\section{АРЕФЬЕВА ЕЛЕНА}

доктор экономических наук, профессор, заведующая кафедры экономики воздушного транспорта, Национальный авиационный университет, г. Киев, Украина

\section{ФОРМИРОВАНИЕ КОНКУРЕНТНОГО ПРЕИМУЩЕСТВА АВИАКОМПАНИИ НА ОСНОВЕ РЕАЛИЗАЦИИ БОРТОВОГО ПИТАНИЯ}

\begin{abstract}
Аннотация. В работе была приведена характеристика сущности конкурентных преимуществ. В статье обосновывается необходимость реализации конкурентных преимуществ на рынке пассажирских авиаперевозок. Предлагается формирование конкурентных преимуществ на основе бортового питания и обосновывается привлекательность таких преимуществ. В работе анализируется рынок бортового питания. Исследуются особенности предоставления услуги бортового питания в Украине. В статье отображаются основные проблемы и недостатки рынка бортового питания в Украине. На основе проведённых исследований предлагаются меры касательно преобразования недостатков рынка бортового питания в конкурентное преимущество авиакомпаний. Реализация предложенных мер даст возможность авиаперевозчику качественно улучшить свой имидж, иметь особенную черту, которая будет сильно улучшать спрос на услуги предприятия, что характерно выделит авиапредприятие среди конкурентов и даст возможность пассажиру утолить голод, а также получить желаемый, в постмодернистском обществе, комфорт. А уже именно комфорт пассажиров есть большое конкурентное преимущество авиаперевозчика.
\end{abstract}

Целью данной статьи является теоретическое обоснование и разработка практических рекомендаций мер касательно формирования конкурентных преимуществ авиакомпаний на основе реализации бортового питания. Актуальность выбранной темы обусловлена насыщенной конкурентной борьбой авиакомпаний на рынке Украины, необходимостью компаний бороться за наименьшие преимущества в то время, когда, ведущему направлению в формировании конкурентных преимуществ в мире, бортовое питание, совсем не уделяется внимание.

Научную новизну полученных результатов составляет разработка рекомендаций касательно использования бортового питания как элемента конкурентной борьбы. Практическая ценность заключается в возможности использования рекомендаций на всех авиапредприятиях Украины.

\footnotetext{
(C) Українська інженерно-педагогічна академія

(c) ГО «Школа адаптивного управління сочіально-педагогічними системами»

(C) Храпач B., Ареф''єва О.
} 
Ключевые слова: конкурентное преимущество, конкурентная борьба, бортовое питание, кейтеринг, пассажирские авиаперевозки.

\author{
KHRAPACH VLADISLAV \\ magister, National aviation university, Kiev, Ukraine
}

\begin{abstract}
AREFIEVA OLENA
Doctor of Economics, Professor, Head of the Department of Air Transport Economics, National aviation university, Kiev, Ukraine
\end{abstract}

\title{
CREATION OF AN AIRLINE COMPETITIVE ADVANTAGE USING IN-FLIGHT CATERING
}

Summary. The nature of competitive advantages is presented in the paper. The article justifies the need to realize competitive advantages in the passenger air transportation market. It proposes to create competitive advantages using in-flight catering and justifies attractiveness of such advantages. The paper analyzes the inflight catering market. Peculiarities of in-flight catering service provision in Ukraine are investigated. The article reveals the main problems and weaknesses of Ukrainian in-flight catering market. Based on the outcomes of the research, measures on transforming the weaknesses of in-flight catering market into airlines competitive advantage are proposed. Implementation of the proposed measures will allow the airline to significantly improve its image, have a special feature that would greatly increase the demand for this company's service thus differentiating the airline company from among the competitors, and will allow the passengers to both satisfy their hunger and experience the feeling of comfort craved for by the post-modern society. And it is comfort of the passengers, which is a great competitive advantage of the airline.

The purpose of this article is to provide theoretical justification and to develop practical recommendations as to the measures on creation of airlines competitive advantages using in-flight catering. The relevance of the chosen subject is based on a strong competition among airline companies at Ukrainian market and the need for the companies to compete for even minor advantages, while the key issue for creation of competitive advantages in the world, which is in-flight catering, is being disregarded.

The scientific novelty of the outcomes consists in development of recommendations concerning the use of in-flight catering as an element of competition. The practical value lies in the opportunity to use the recommendations by all Ukrainian airline companies.

Key words: competitive advantage, competition, in-flight catering, catering, passenger air transportation.

\footnotetext{
(C) Українська інженерно-педагогічна академія

(c) ГО «Школа адаптивного управління сочіально-педагогічними системами»

(C) Храпач В., Ареф'єва О.
} 